\title{
DISTRIBUTION AND ECOLOGY OF GRIMMIA (GRIMMIACEAE, BRYOPHYTA) IN MONGOLIA
}

\section{РАСПРОСТРАНЕНИЕ И ЭКОЛОГИЯ МОНГОЛЬСКИХ ВИДОВ РОДА GRIMMIA (GRIMMIACEAE, BRYOPHYTA)}

\author{
TS. TSEGMED ${ }^{1} \&$ E.A. IGNATOVA ${ }^{2}$ \\ Ц. ЦЭГМЭД ${ }^{1}$, Е.А. ИГНАТОВА ${ }^{2}$
}

\begin{abstract}
Revision of numerous collections from Mongolia revealed 15 species of Grimmia. Most of them are high-mountain species, known mainly from the western part of the country, especially in Mongolian Altai. The most widespread is Grimmia longirostris, that avoids however xeric regions of Gobi (although occurring in Gobi Altai in very high mountains). Very similar is the distribution of G. elatior, that is however widespread, but somewhat less common. The most common in the xeric regions of Gobi (and occurring in other parts of Mongolia as well), are G. tergestina and G. anodon. The latter species is relatively more common in western parts of country, whereas distribution of $G$. tergestina is especially associated with flat xeric territories. East Asian (and Eastern North American) G. pilifera is common, but in a rather restricted area of Mongolian Dauria and Khentei and westward to Khubsugul and East Khangai.
\end{abstract}

Резюме

Определение обширных коллекций из Монголии выявило на территории этой страны 15 видов Grimmia. Большинство из них - это высокогорные виды, известные по единичным находкам преимущественно с запада Монголии, особенно из Монгольского Алтая. Наиболее распространена Grimmia longirostris, которая избегает, однако, слишком засушливых районов Гоби (хотя встречается там в наиболее высоких горах). Сходно распространение у G. elatior, которая также широко распространена, но не столь массова. Наиболее ксерофитными по характеру распространения в стране можно считать два вида, проникающие в Гоби, хотя и встречающиеся в большинстве районов страны, G. tergestina и $G$. anodon. Последний вид явно более част в более западных районах Монголии, тогда как G. tergestina теснее других связана с относительно равнинными аридными территориями. Восточноазиатская (и восточно-североамериканская) G. pilifera довольно обильно встречается в ограниченном районе в Монгольской Даурии, Хэнтэе, восточном Хангае и Прихубсугулье.

The check-list of Mongolia listed 17 species of Grimmia (Tsegmed, 2001). After that, the second author revised all the collections of the genus made mostly by the first author, in Herbarium of Institute of Botany in Ulaan-Baatar (duplicates in MHA). In addition, specimens collected in 1970 s by Soviet-Mongolian expedition (LE, duplicates in UlaanBaatar and MHA) were identified.
Grimmia alpestris (F. Weber \& D. Mohr) Schleich. On cliffs and rocks on dry S-facing mountain slopes, in alpine belt. $2800-3100 \mathrm{~m}$ alt.

Distribution: Mongolian Altai: Mountain ridges Indertijn nuuru and Shaazgaityn nuuru.

Grimmia anodon Bruch et al. - On rocks in rock-fields, in Kobresia-dominated tundra, on rocky slopes, in various steppes and other open sites. Common in steppe and semi-desert areas. 1900-3300 m alt.

1 - Institute of Botany, Academy of Science of Mongolia, Ulaanbaatar 51, Mongolia.

2 - Biological Faculty, Moscow State University, Moscow 119991 Russia - Россия 119991 Москва, Московский государственный университ, Биологический факультет, каф. геоботаники. 


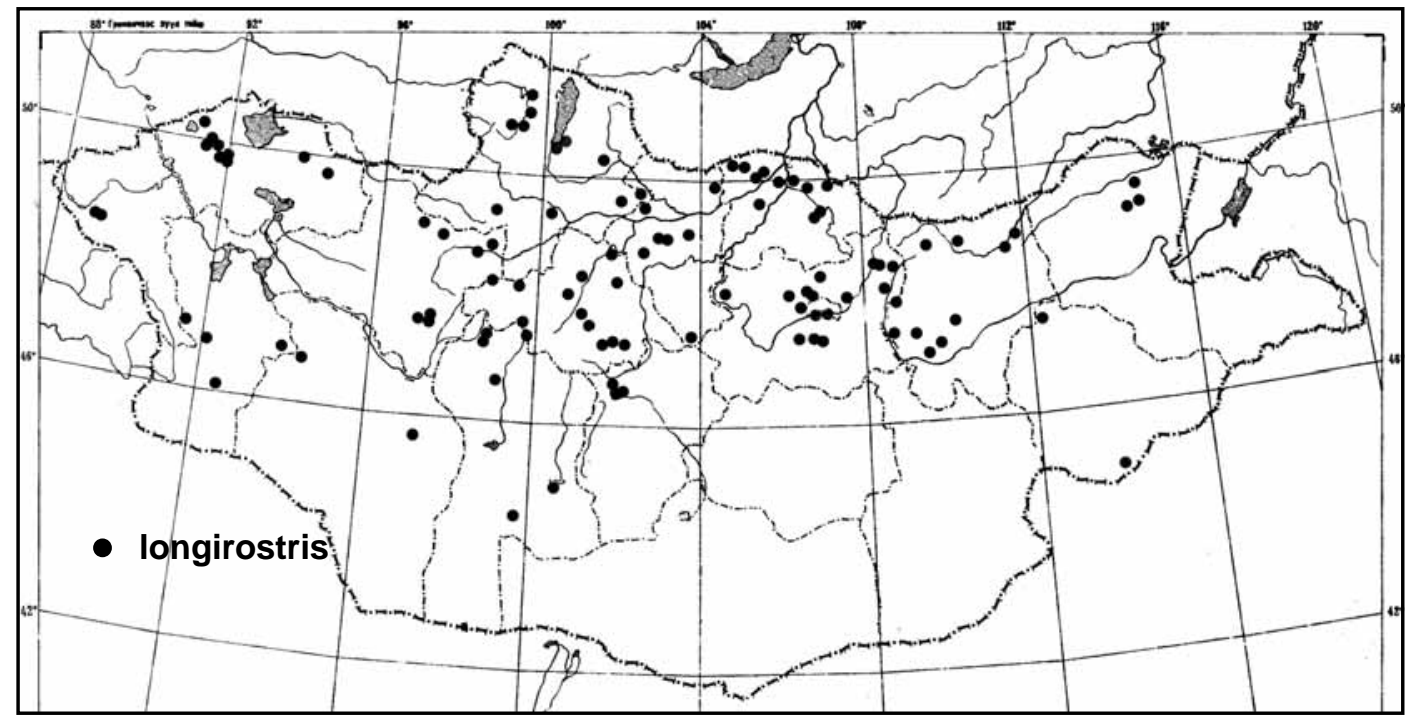

Distribution: Khubsugul: Darkhat depression Mt. Toshloj; Lake Khubsugul - SW surroundings of the lake, Zhankhaj Ravine; Khaentaej: Mt. Bogd uul - Ravine Shazhin khurakh; Khangaj: Range Khan-Khukhej, basin of the River Orkhon - Khuntyn Rashaan and Undrakh, Lake Taerkhijn Tsagaan nuur, Range Suvraga Khairkhan - Mt. Ondgij; Mongolian Dauria: $34 \mathrm{~km}$ from Undurkhan along the road to Norovlin somon; Khovd: Range Kharkhiraa - Khar Tarbagataj, Umnu-Otor uul, Range Turgaen - Gorge Yamaat, Range Tsagaan Shuvuut, Lake Achit nuur, Lake Uuraeg nuur, Range Sijlkhaemijn nuruu - Lake Tsagaan nuur, Plane Khar govi - 16 $\mathrm{km}$ south of Tsagaannuur somon along the road to Bayan-Ulgij; Mongolian Altai: Lake Dayan nuur, Mt. Munkh Khajrkhan - Pass Ulaan dabaa, Range Zast uul - surroundings of Lake Doroo nuur, Mountain Taemaeaenij Khukh uul - along the road from Tsaetsaeg somon to Must somon, Range Sutaj Khajrkhan uul - valley of the River Baelchaerijn khudag, Range Khar Azargyn nuruu, SE part of Mongolian Altai - Ranges Indaertijn nuruu, Rashaantyn nuruu and Shaazgajtyn nuruu, River Bulgan gol, Mt. Alag Khajrkhan uul, Main Range of Mongolian Altai - Valley Bugyn khundij, Pass Daerstijn dabaa, Range Gichgaenij nuruu - Khukh dabaa, Ulzijt Ravine, Range Azh Bogd - Mt. Ikh Oboo, Mt. Burkhan Buudaj uul, Mt. Khasagt Khajrkhan; Hollow of Great Lakes: $14 \mathrm{~km} \mathrm{~W}$ of Ulzijt somon, southern slope of Range Darvijn nuruu; Gobi-Altai: Range Bayan Tsagan; Mt. Ikh Bogd uul; Mt. Dtsun-Saykhan; Range Khuraen Khanyn nuruu; Mt. Tost uul; Dzhungarian Gobi: Mt. Uvchugiyn Saevraen uul; Mt. Saertaengijn Khuvch uul, Range Dzun-argalant uul.
Grimmia donniana Sm. - On rocky slopes and rockfields in alpine belt. 2900-3220 m alt.

Distribution: Khangaj: Range Khankhukhaej, Khovd: Range Kharkhiraa - Mt. Umnu-Otor uul, Range Turgaen - Mt. Yamaat, southern slope of Tirgaen Mt. - Mt. Gashguurt, Mongolian Altai: Range Indaertijn nuruu - Mt. Khargajt.

Grimmia elatior Bruch ex Bals.-Griv. \& De Not. - On rocks and cliffs in upper forest belt, on rocky summits of mountains and rock-fields in alpine belt. 1200-3350 m alt.

Distribution: Khubsugul: River Daelgaer murun; Khaentaej: River Sharyn gol - Ravine Monostoj, Khujtnij gol, Estijn rashaan, River Sugnugur, River Bayangol, Gorkhi, Mt. Bogd uul - Ravine Nujht, Zalaat, Dzun bogino, Shazhin khurakh, Mandshirijn khijd, Baruum Shiraeaet, Tsaetsaeae Gun; Khangaj: Range Aerchmijn nuruu, Mt. Dulaankhan, Range Khan-Khukhaej - Mt. Saalig, Mt. Dzun-Un't, Range Tarbagataj - Pass Solongot, northern slope of Tarbagataj Range - Khozhuulyn gol, Lake Taerkhijn Tsagaan nuur, Mt. Toont uul, Mt. Numrug uul, Mt. Otgontaengaer - upper course of Chuluur River and Bogd gol, Lake Khukh nuur, Main Range of Khangaj - Lake Najman nuur, upper course of River Ulaana gol, basin of River Orkhon, Range SuvragaKhajrkhan, Mt. Khan-Undur uul, Mt. Khutag uul, mouth of River Altaidyn gol, Mt. Khugnae-Khaan uul; Mongolian Dauria: Range Khustajn nuruu Ravine Khushuut, Mt. Sant uul, Shuvuun dabaa, Dugan khad; Khovd: Range Turgaen - valley of the River Turgaen, Gorge Yamaat, Range Kharkhiraa River Mukhar Uliastaj, River Goozhuuryn gol, Mongolian Altai: Lake Dayan nuur - Ravine Khijtaen salaa, south-eastern part of Mongolian Altai - Range 


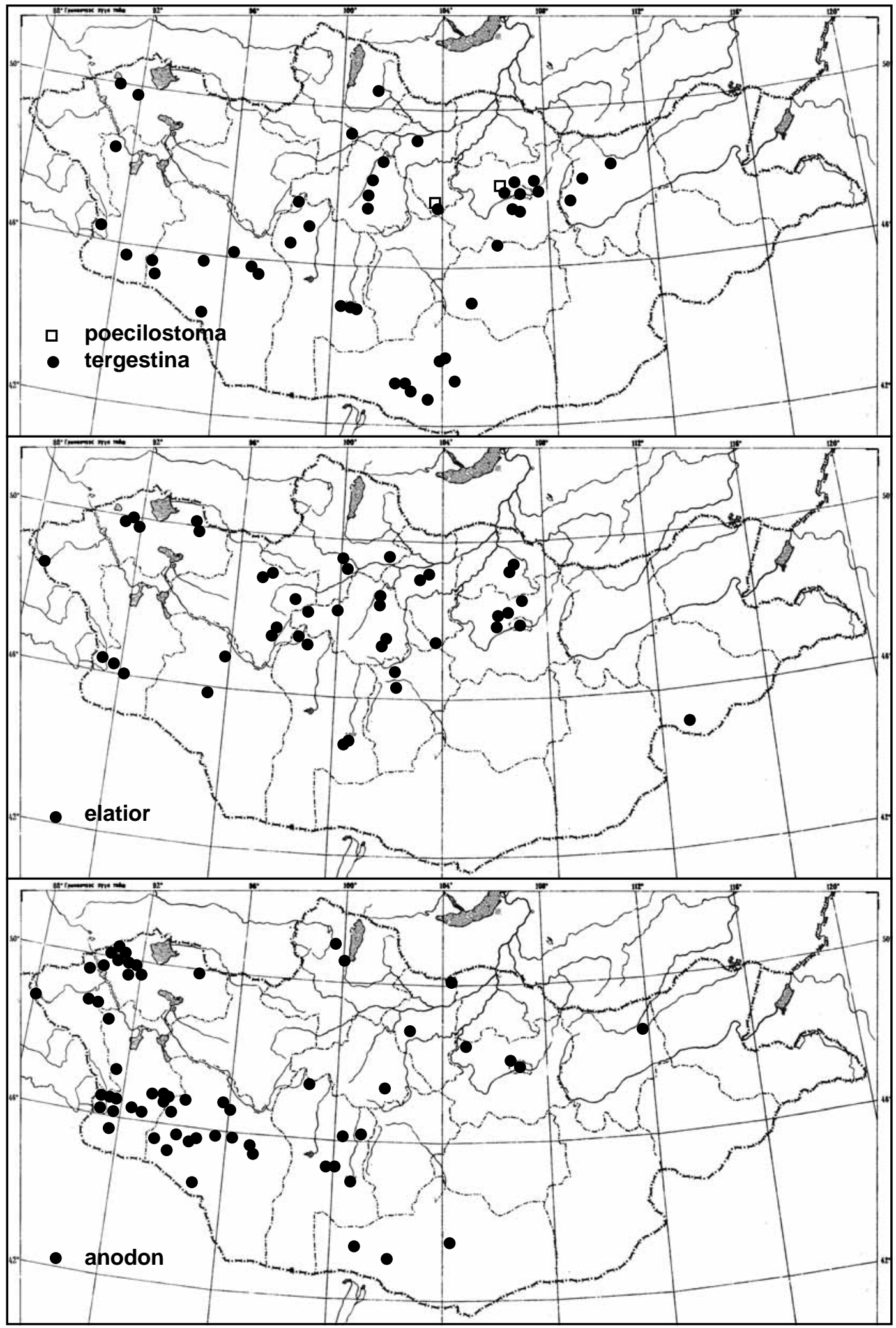




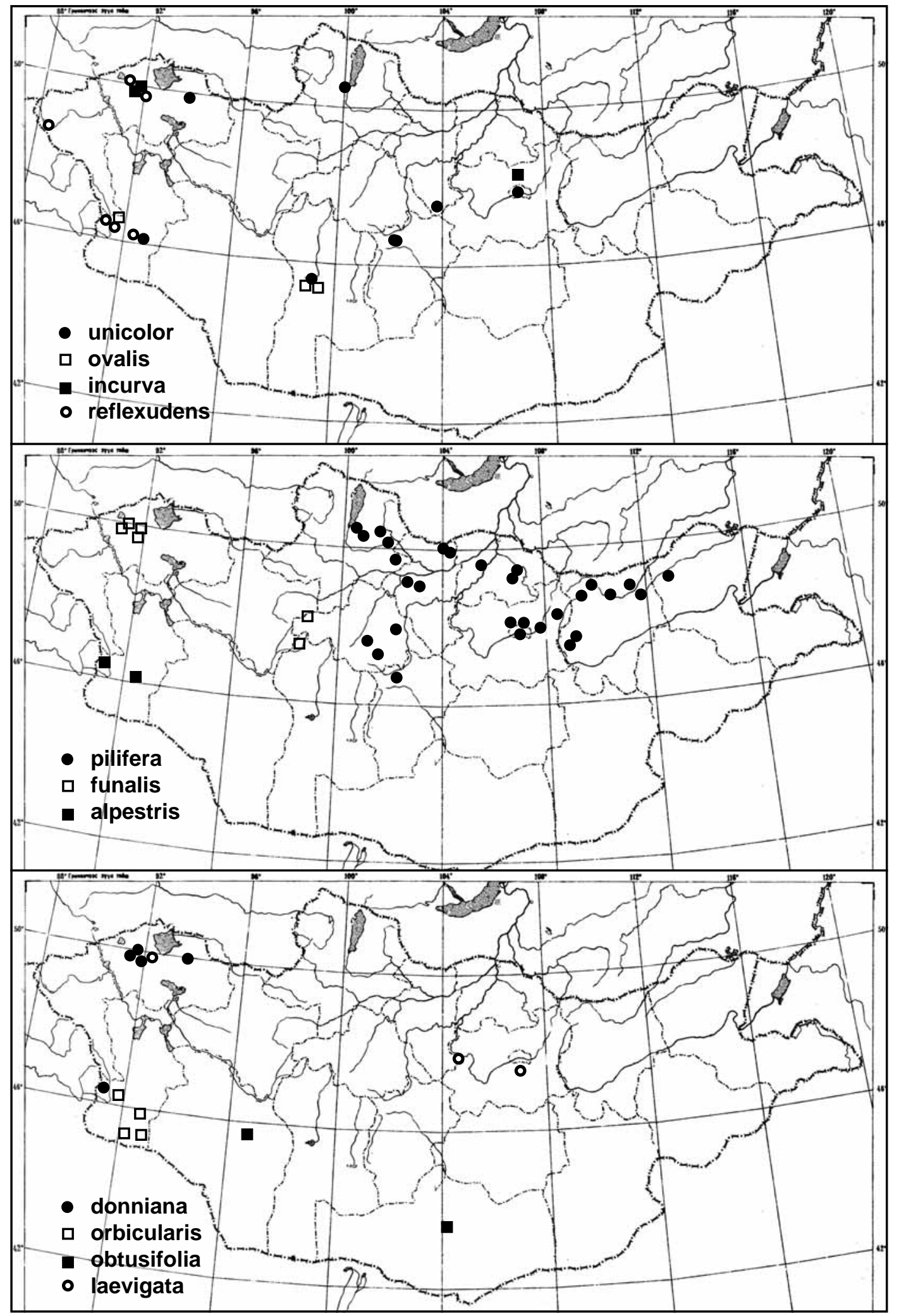


Rashaant, Indaert, Range Shaazgajtyn nuruu, Main Range of Mongolian Altai - Pass Daerstijn dabaa; Eastern Mongol: Mt. Shilijn Bogd uul; Gobi-Altai: Mt. Ikh Bogd uul.

Grimmia funalis (Schwägr.) Bruch et al. - Mostly in alpine belt, on rocks and cliffs in mountain tundra, Kobresia-dominated steppes and on rock-fields. 2600-3000 m alt.

Distribution: Khangaj: Main Range of Khangaj-Tarbagataj, Lake Khukh nuur; Khovd: Range Turgaen Mt. Yamaat, Mt. Gashguurt, Range Kharkhiraa-Gorge of River Mukhar Uliastaj, Mt. Khar Tarbagataj.

Grimmia incurva Schwägr. - In cliff crevices on rocky slopes and rock-fields, in alpine belt. 3070-3220 m alt. Rare in Mongolia.

Distribution: Khaentaej: Spring Estij; Khovd: Range Turgaen - Mt. Yammat, southern slope of Turgaen Range - Mt. Gashguurt.

Grimmia laevigata (Brid.) Brid. - On dry rocks and cliffs, in cliff crevices, in dry and open habitats. 1000$1500 \mathrm{~m}$ alt. Rare in Mongolia.

Distribution: Khovd: Ulaangom - Ulaantolgoj (coll. N. Ulzijkhutag); Mongolian Dauria: $1 \mathrm{~km} \mathrm{~W}$ of Lun somon (coll. \& det. V.Shubert), Middle Halha: Mt. Bayasgalant uul, near Unzhuul somon (coll. N.Golubkova \& U. Tsogt).

Grimmia longirostris Hook. - On rocks in forest and alpine belts, also in steppe belt in mountains. Most widespread species of the genus in Mongolia. 1000$3050 \mathrm{~m}$ alt.

Distribution: Khubsugul: SE surroundings of Lake Khubsugul, Darkhat depression - River Shishkhit, River Taengis gol, Mt. Uvulzhuu uul, Mt. Khar Murugu uul, Pass Bogozhijn dabaa, Daelgaermurun River basin - Mt. Saerkh uul, basin of the River Aegijn gol - Pass Urtyn dabaa; Khaentaej: Spring Estij - Mt. Oyuut uul, NW Khaentij - upper course of the River Khujtnij gol, Ravine Monostoj, Range Burkhijn dabaa - upper course of the River DzunBurkhijn gol, River Dzun, River Baruun Burkhijn gol, Gorkhi, valley of the River Taeraelzhijn gol, western part of Malyj Khaentaej - River Sugnugur, River Bayangol, Mt. Bogd uul - Ravine Nukht, Tur khurakh, Mandshirijn khijd, Tsaetsaeae Gun, Baruun Shiraeaet; Khangaj: Range Aerchmijn nuruu, Range Khajtajn nuruu - Mt. Namnan uul, Mt. Chchirt, Mt. Khutag uul, Mt. Dulaankhaan, Range Khan-Khukhaej, Mt. Numrug, Mt. Toont, northern slope of Tarbagataj Range, Pass Sologot, Lake Taerkhijn Tsagaan nuur, Mt. Otgontaengaer, Range Suvraga-Khajrkhan, valley of the River Khukh Sum, River Tsatsaerlaeg, River Chuluutyn gol, Pass Aegijn dabaa, Mt. Asgat turuu, River Okh Tamir, valley of the River Khuzhirt, Mt. Khan-Undur uul, mouth of the River Altaid, Lake Najman nuur, upper course of the River Ulaana gol, Lake Khukh nuur, valley of the River Bajdrag gol, basin of the River Orkhon gol - Khuntyn rashaan, Mt. Khugnae-Khaan uul, Mt. Batkhaan, Range Butaeaelijn nuruu - River Orookh, River Shavartyn gol, River Khaeraegchin, valley of the River Saelaenga, Bureaengijn nuruu Eaevaengijn gol; Mongolian Dauria: basin of the River Orkhon - Mt. Dulaankhan, Mt. Daelgaerkhangaj, Range Khustaj, Mt. Dugan khad, Mt. Zorgol Khajrkhan uul, Range Aeraeaen dabaa, valley of the River Onon gol, River Aegijn gol, Mt. Khutag Khajrkhan uul, basin of the River Kerulaen - Mt. Buraen, basin of the River Ulzijn gol - Mt. Ulzij-Sajkhan, Pass Durvulzhigijn dabaa; Khovd: Range Tsagaan shuvuut, Range Turgaen - valley of the River Turgaenij gol, Gorge Yamaat, Range Kharkhiraa - Mt. Umnu-Otor uul; Mongolian Altai: Lake Dayan nuur - Mt. Yamaat, Mt. Songinot, Pass Songinotyn dabaa, Ravine Altan salaa, Mt. Munkh Khajrkhan - Lake Doloon nuur, Range Sutaj Khajrkhan - Mt. Tsast uul, Range Shaazgajtyn nuruu, Range Gichgaenij nuruu, southern slope of Range Darvijn nuruu; Gobi-Altai: Mt. Shinae Zhinst uul, Mt. Ikh Bogd uul - upper course of the River Shatat; Middle Khalkha: Mt. Unzhuul uul, Mt. Bayasgalant uul; Eastern Mongol: Mt. Bayan uul, Mt. Shilijn Bogd uul.

Grimmia obtusifolia C.H. Gao \& T. Cao. - On rock surface. 1600-2670 m alt.

Distribution: Mongolian Altai: Mt. Khasagt Khajrkhan, Range Gichgaenij nuruu - Ravine Shavart; Gobi-Altai: Mt. Dzun-Sajkhan. Dzhungarian Gobi: Mt. Saertaengijn Khuvch uul.

Grimmia orbicularis Bruch ex Wilson. - On rocks and cliffs.

Distribution: Mongolian Altai: Range Indaertijn nuruu - Uliastajn am.

Grimmia ovalis (Hedw.) Lindb. - On rocks and cliffs in alpine belt. $2800-3300 \mathrm{~m}$ alt.

Distribution: Mongolian Altai: Range Rashaantyn nuruu - Mt. Khargayt; Gobi-Altai: Mt. Ikh-Bogd uul.

Grimmia pilifera P. Beauv. - On rocks and cliffs, mainly within forest belt and in hilly steppes. $1230-1840 \mathrm{~m}$ alt. Distribution: Khubsugul: SE coast of Khubsugul Lake; Pass Tsagan davaa; River Arigijn gol; basin of River Aegijn gol - Pass Urtyn divaa; 7 km N of Tarilan somon to the Aerdaenae-Bulgan; Khaentaej: NW Khaentaej - Ravine Monostojn am, Ravine Ar Gakhajt, River Bayangol, Mt. Khandgajt - Ravine Zhigzhidijn am, Mt. Bogd uul - Ravine Nukht, eastern Khaentaej - Gorkhi, River Taeraelzhijn gol; Khangaj: Main Range of Khangai - uppur course of the River Ulaana gol, Mt. Khan-Undur, River Ikh Tamir, River Tsaetsaerlaeg, Range Khantajn nuruuMt. Chachirt, mouth of the River Altaid, Range Butaeaelijn nuruu - River Orookh, River Shirmaen, Riv- 
er Shavart, Range Buraengijn nuruu - upper course of the River Eaevaengijn gol; Mongolian Dauria: basin of the River Kerulaen - Mt. Buraen, $31 \mathrm{~km}$ of Zhargaltkhan somon along the road to Undurkhan, goskhoz Kerulaen $-34 \mathrm{~km}$ of Undurkhan along the road to Norovlin somon; valley of the River Khurkhyn gol-Mt. Aerdaenae-Tsogt uul, Mt. Dund Nomgon uul, valley of the River Onon gol; Eastern Mongol: Mt. Bayan uul.

Grimmia poecilostoma Cardot \& Sebille. - On rocks and cliffs in dry and open habitats. $1600-2840 \mathrm{~m}$ alt. Distribution: Khangai: Main Range of Khangaj, Mt. Gurvan bulag (coll. S.V. Maximovich); Mongolian Dauria: Range Khustai-Ikh Ovoot.

Grimmia reflexidens Müll. Hal. (=G. sessitana De Not.) - On rock faces on rocky slopes and summits, mainly in high mountains. 2450-3100 m alt.

Distribution: Khovd: Range Turgaen, Mt. Yamaat; southern slope of Range Turgaen, Mt. Gashguut; Range Kharkhiraa - Mt. Umnu-Otor uul; Mongolian Altai: Lake Dayan nuur - Ravine Khujtaen salaa, Range Indaertijn nuruu - Mt. Bayankhairkhan, Range Rashaantyn nuruu - River Dood narijn gol, Range Shaazgajtyn nuruu - Mt. Atsag.

Grimmia tergestina Tomm. ex Bruch et al. - On rocks and cliffs, in crevices, mostly on dry mountain slopes and summits. 1400-3100 m alt.

Distribution: Khubsugul: surroundings of southern shore of Khubsugul Lake - Pass Zhankhajn dabaa, basin of the River Aegijn gol - Pass Urtyn dabaa; Khaentaej: River Bayangol, Gorkhi, valley of the River Taeraelzhijn gol, Khangaj: mouth of the River Idaer murun, Range Khantaj - Mt. Chachirt, River Ikh Tamir, valley of the River Khuzhirt, valley of the River Chuluut, Mt. Asgat Turuu, Lake Khukh nuur, valley of the River Bajdragijn gol, Mt. Gurvanbulag; Khovd: Range Kharkhiraa - Mt. UmnuOtor uul, Pass Zaelaegnijn khutul, Mongolian Dauria: Range khustaj-Mt. Sant, Mt. Aerdaenae-Tsogt, Mt. Artsat uul, Ravine Mojltyn am, Mt. Zorgol Khajrkhan, Mt. Unzhuul uul; valley of the River Onon gol, valley of the River Kerulaen - Mt. BayanUlaan, valley of the River Khurkhyn gol - Mt. Aerdaenae-Tsogt uul, Mongolian Altai: Range Tajshiryn nuruu, Range Khar-azargyn nuruu; Range Rashaantyn nuruu - Mt. Mogojt uul, Mt. Azh Bogd uul Mt. Ikh Oboo, Mt. Alag Khajrkhan uul, Range Mongolian Altai - along the road from Bayantooroj to Tsogt somon, southern slope of Range Darvijn nuruu; Middle Khalkha: Mt. Adaatsag, Tsakhir brigad
- Middle Gobi ajmag, Aerdaenae dalaj somon; Hollow of Great Lakes: sands $10 \mathrm{~km}$ N-NE of Aerdaenae-Khairkhan somon; Gobi-Altai: Mt. Ikh-Bogd uul - upper course of the River Shatat, Mt. Arts Bogd uul, Mt. Dzun-Sajkhan - Ravine Elyn am, Range Khuraen Khanyn nuruu - valley of the River Sara, Mt. Noen uul, Mt. Tost uul, Mt. Nomgon uul; Dzhungarian Gobi: Mt. Uvchugijn Daevraen uul, Mt. Saertaengijn Khuvch uul, Dzun-Argalant uul.

Grimmia unicolor Hook. - On rocks and cliffs on slopes and ridges. 1600-3200 m alt.

Distribution: Khubsugul: surroundings of the southern shore of Khubsugul Lake - Ravine Zhankhajn am; Khaentaej: Mt. Bogd uul - Ravine Nukht; Khangaj: Range Khan-Khukhaej, Main Range of Khangaj - upper course of Ulaana gol, Mt. Khugnae-Khaan uul; Mongolian Altai: Range Shaazgajtyn nuruu; Gobi-Altai: Mt. Ikh Bogd uul, Mt. DzunSajkhan uul.

SPECIES EXCLUDED FROM THE MOSS FLORA OF MONGOLIA

Grimmia fuscolutea Hook. (=G. apiculata Hornsch.)

Grimmia elongata Kaulf.

Grimmia montana Bruch et al.

Grimmia pulvinata (Hedw.) Sm.

Grimmia trichophylla Grev.

DISCUSSION

Most flat territory of Mongolia has elevations of 1100-1400 m; it is a xeric area, especially its south that is totally forestless including mountains. Middle elevations in the northern part of country have forests up to ca. $2000 \mathrm{~m}$, which however intermixed with steppe vegetation. The diversity of Grimmia in deserts is low: the commonest is $G$. tergestina, not rare is also G. anodon (that occur however only above $1900 \mathrm{~m}$ ), while G. obtusifolia is known in Mongolia from 2 localities, both in desert areas. Grimmia poecilostoma and G. laevigata occur in steppes at low elevation, but rare. Within the forest belt, there are G. longirostris, widespread throughout country except deserts, $G$. elatior, moderately common, and G. pilifera, common in a rather restricted area in NE of Mongolia. Other species occur mainly in high mountains, concentrating in regions with the most high peaks in the NW part of the country.

\section{LITERATURE CITED}

